\title{
The Network Paradigm in Organizational Research: A Review and Typology
}

\author{
Stephen P. Borgatti* \\ Department of Organization Studies, Carroll School of Management, Boston College, \\ Chestnut Hill, MA 02467, USA \\ Pacey C. Foster \\ Department of Organization Studies, Carroll School of Management, Boston College, \\ Chestnut Hill, MA 02467, USA
}

Received 28 February 2003; received in revised form 19 May 2003; accepted 21 May 2003

In this paper, we review and analyze the emerging network paradigm in organizational research. We begin with a conventional review of recent research organized around recognized research streams. Next, we analyze this research, developing a set of dimensions along which network studies vary, including direction of causality, levels of analysis, explanatory goals, and explanatory mechanisms. We use the latter two dimensions to construct a 2-by-2 table cross-classifying studies of network consequences into four canonical types: structural social capital, social access to resources, contagion, and environmental shaping. We note the rise in popularity of studies with a greater sense of agency than was traditional in network research. (C) 2003 Elsevier Inc. All rights reserved.

The volume of social network research in management has increased radically in recent years, as it has in many disciplines. Indeed, the network literature is growing exponentially, as shown in Figure 1. The boom in network research is part of a general shift, beginning in the second half of the 20th century, away from individualist, essentialist and atomistic explanations toward more relational, contextual and systemic understandings. The shift can be seen in fields as diverse as literary criticism, in which consideration of literary works as self-contained immutable objects has given way to seeing texts as embedded in a system of meaning references decoded by myriad interacting readers (Barthes, 1977; Kristeva, 1980), and physics, in which there is no hotter topic than modeling the evolution of every kind of network including collaboration in the film industry and co-authorship among academics (Barabasi, 2002; Newman, 2002).

\footnotetext{
* Corresponding author. Tel.: +1-617-552-0450; fax: +1-617-552-4230.

E-mail address: borgatts@bc.edu (S.P. Borgatti).
} 


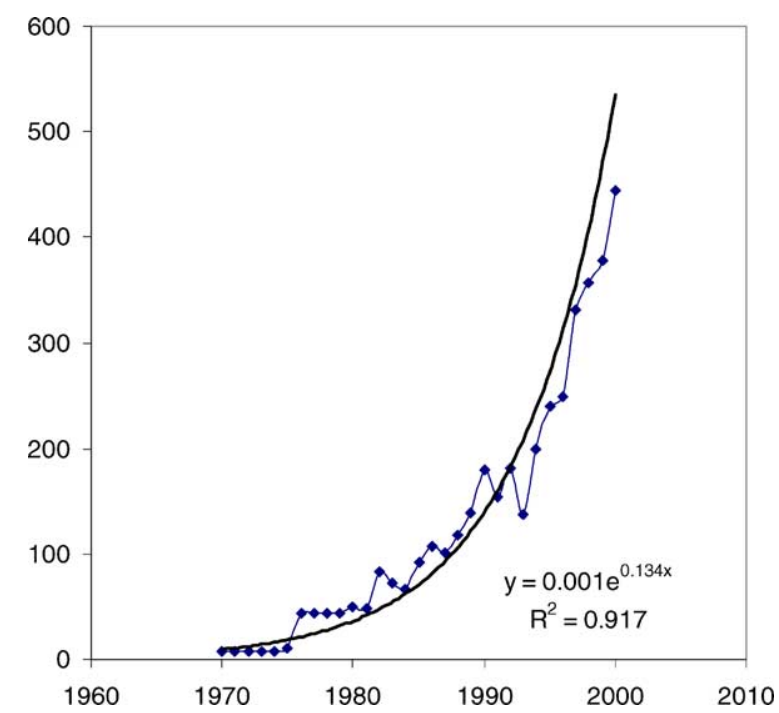

Figure 1. Exponential growth of publications indexed by Sociological Abstracts containing "social network" in the abstract or title.

The rapid increase of network research in management creates the need for a review and classification of what is being done in this area. That is the objective of this paper. We begin our effort with a conventional review of the recent literature, organizing the work around accepted research areas and pointing out current issues. Following this is a section in which we re-organize the material into our own categories, highlighting theoretical mechanisms and functions of ties. This allows us to make connections across research areas and draw some more abstract conclusions about what kinds of work are being done.

For those not familiar with network research, we start by introducing a bit of terminology. A network is a set of actors connected by a set of ties. The actors (often called "nodes") can be persons, teams, organizations, concepts, etc. Ties connect pairs of actors and can be directed (i.e., potentially one-directional, as in giving advice to someone) or undirected (as in being physically proximate) and can be dichotomous (present or absent, as in whether two people are friends or not) or valued (measured on a scale, as in strength of friendship). A set of ties of a given type (such as friendship ties) constitutes a binary social relation, and each relation defines a different network (e.g., the friendship network is distinct from the advice network, although empirically they might be correlated). Different kinds of ties are typically assumed to function differently: for example, centrality in the "who has conflicts with whom' network has different implications for the actor than centrality in the 'who trusts whom' network. When we focus our attention on a single focal actor, we call that actor "ego" and call the set of nodes that ego has ties with "alters." The ensemble of ego, his alters, and all ties among these (including those to ego) is called an ego-network. Since ego-networks can be collected for unrelated egos (as in a random sample of a large population), ego-network studies blend a network-theoretic perspective with conventional, individual-oriented methods of collecting and processing data. 


\section{Review of Current Research}

In this section, we provide a brief review of some of the major research streams in organizational network scholarship. The review is organized by the following emic categories: social capital, embeddedness, network organizations, board interlocks, joint ventures and inter-firm alliances, knowledge management, social cognition, and a catch-all category we have labeled "group processes." Embeddedness, network organization, board interlocks and joint ventures/alliances are becoming so closely intertwined that they could be reviewed together. However, it is our feeling that there are enough differences to keep them separate. We note that the ordering of categories is largely macro to micro; the notable exception is social capital which is mostly studied at the individual level (at least in organizational research), but which has a macro side as well. We also note that while the objective is to review current research (primarily the last five years), we include older references in order to anchor a stream of work in a research tradition. Finally, the reader may find it helpful to keep in mind that (a) network variables can and do serve as both dependent and independent variables, and (b) the different research areas differ characteristically in terms of which role is dominant (e.g., in social capital research the focus is on network variables as explanatory, while in alliance research, the focus is typically on network ties as the outcome of an organizational process).

\section{Social Capital}

Probably the biggest growth area in organizational network research is social capital, a concept that has symbiotically returned the favor and helped to fuel interest in social networks. In the most general terms, the concept is about the value of connections. It should be recognized that, to a great extent, social capital is "just" a powerful renaming and collecting together of a large swath of network research from the social support literature (Walker, Wasserman \& Wellman, 1994) to social resource theory (Lin, 1982, 1988). In management, social capital promises to bring together a variety of research relating a person's ties or network position to significant outcomes such as power (Brass, 1984; Brass \& Burkhardt, 1993; Kilduff \& Krackhardt, 1994), leadership (Brass \& Krackhardt, 1999; Pastor, Meindl \& Mayo, 2002; Sparrowe \& Liden, 1997), mobility (Boxman, De Graaf \& Flap, 1991; Burt, 1997; Seibert, Kraimer \& Liden, 2001; Seidel, Polzer \& Stewart, 2000), employment (Fernandez, Castilla \& Moore, 2000; Krackhardt \& Porter, 1985, 1986), individual performance (Baldwin \& Bedell, 1997; Mehra, Kilduff \& Brass, 2001; Sparrowe, Liden, Wayne \& Kraimer, 2001), individual creativity (Burt, 2003; Perry-Smith \& Shalley, 2003), entrepreneurship (Baron \& Markman, 2003; Renzulli, Aldrich \& Moody, 2000; Shane \& Stuart, 2002), and team performance (Hansen, 1999; Tsai, 2001). Detailed reviews are available by Adler and Kwon (2002), Portes (1998), and Lin (2001).

While much of the earlier work on these organizational themes generally characterized social capital as ties to resource-filled others, the publication of Burt's structural holes book (1992) redirected attention to the shape or topology of an actor's ego-network. Specifically, Burt equates social capital with the lack of ties among an actor's alters, a condition he names structural holes. He argues that the spanning of structural holes provides the actual mechanism relating weak ties to positive outcomes in Granovetter's (1973) strength of weak ties theory. Burt's view contrasts with Coleman's (1990) equally topological view of social 
capital, which calls for a dense ego-network in which ego's alters are able to coordinate with each other to help ego. Coleman's view is similar to that of Putnam (2000) and others who define a group's social capital in terms of broad cross-cutting interconnections among all group members. For example, Putnam (2000) famously bemoans the fact that even though bowling has increased in popularity in the US over the years, bowling in leagues has declined. The ties created by such associations as organized bowling leagues are thought to knit together a society, ultimately contributing to a society's ability to prosper. The argument is virtually identical to Granovetter's (1973) classic analysis of Boston neighborhoods, though Granovetter doesn't use the term social capital. The contrast in views of optimal network shapes has sparked a fruitful series of papers (Burt, 2001; Gargiulo \& Benassi, 2000; Podolny \& Baron, 1997).

A similar and related line of investigation reverses the usual logic of social capital and examines the negative consequences of social capital-the so-called "dark side" in which social ties imprison actors in maladaptive situations or facilitate undesirable behavior (Gargiulo \& Benassi, 1999; Gulati \& Westphal, 1999; Portes \& Landolt, 1996; Portes \& Sensenbrenner, 1993; Putnam, 2000; Volker \& Flap, 2001).

Another new development in the social capital literature has been its use in explaining well-known relationships between minority status and job mobility. Seidel et al. (2000) suggest that minorities have fewer ties (i.e., social capital) in the organization, and that people with fewer ties have less successful salary negotiations. Hence, a network process provides the mechanism that relates minority status to less successful salary negotiations. Similarly, McGuire (2000) concludes that network characteristics explain the racial and gender differences in employee status, and James (2000) suggests that social capital mediates the relationship between race and social support among organization managers. Taking the inverse point of view, Burt (1998) examines how gender moderates the relationship between social capital and mobility-finding that structural holes benefit men more than women. See Burt (1997) for additional work on contingencies affecting the value of social capital, a line of work that is also related to the "dark side" stream reviewed above.

\section{Embeddedness}

Like social capital, embeddedness has had fad-like success among organizational scholars, becoming enormously popular shortly after Granovetter's (1985) discussion of the concept. In its initial formulation, embeddedness was basically the notion that all economic behavior is necessarily embedded in a larger social context - that, in effect, economics was a branch of sociology. In particular, Granovetter painted economic exchanges as embedded in social networks, and saw this as steering a middle road between over-socialized (role-based) and under-socialized (purely instrumental rational actor) approaches to explaining economic action. More recent empirical work has focused on the performance benefits of embedded ties, which are often associated with closer and more exclusive business relationships (Uzzi, 1997). A central theme in this research is that repetitive market relations and the linking of social and business relationships generate embedded logics of exchange that differ from those emerging in traditional arms-length market relations (DiMaggio \& Louch, 1998; Uzzi, 1996, 1999; Uzzi \& Gillespie, 2002). Embedded ties have been found to affect the choice of joint venture partners (Gulati \& Gargiulo, 1999), 
the cost of capital (Uzzi, 1999; Uzzi \& Gillespie, 2002), consumer purchasing decisions (DiMaggio \& Louch, 1998), the continuity of client relations (Baker, Faulkner \& Fisher, 1998), and the performance of firms with close ties to both competitors (Ingram \& Roberts, 2000) and suppliers (Uzzi, 1997).

Despite the fact that in discussing his embeddedness perspective Granovetter (1985) explicitly contrasted it with transaction cost economics (Williamson, 1975), later theorists have tended to marry the two (Blumberg, 2001; DiMaggio \& Louch, 1998; Jones, Hesterly $\&$ Borgatti, 1997). Indeed, transaction cost economics (TCE) does seem very consistent with embeddedness theory since TCE is an unmistakably relational theory. In a deeper sense, however, TCE reverses the traditional logic of embeddedness by reasserting the primacy of economic performance as a driver of exchange behavior. For example, the blend of embeddedness and TCE found in Jones et al. (1997) has social ties existing because of the competitive advantage they afford through safeguarding economic transactions. Some have gone as far as explicitly including utility maximization functions in simulation models of embeddedness (Montgomery, 1998). Counterbalancing this trend, Dacin, Ventresca and Beal (1999) revive the work of Zukin and DiMaggio (1990) and emphasize the original conception of embeddedness as context for economic action.

\section{Network Organizations and Organizational Networks}

Intertwined with the embeddedness literature is the literature on network organization (see Baker \& Faulkner, 2002; Podolny \& Page, 1998, for reviews). During the 1980s and 1990s, "network organization" (and related terms) became a fashionable description for organizational forms characterized by repetitive exchanges among semi-autonomous organizations that rely on trust and embedded social relationships to protect transactions and reduce their costs (Bradach \& Eccles, 1989; Eccles, 1981; Jarillo, 1988; Powell, 1990). Much of this research argued that as commerce became more global, hypercompetitive and turbulent, both markets and hierarchies displayed inefficiencies as modes of organizing production (Miles \& Snow, 1992; Powell, 1990). In their place, a network organizational form emerged that balanced the flexibility of markets with the predictability of traditional hierarchies (Achrol, 1997; Miles \& Snow, 1992; Powell, 1990; Snow, Miles \& Coleman, 1992; see Rice \& Gattiker, 2000, for a different view).

While there is general agreement on the benefits of this new organizational form, its ontological status remains somewhat unclear. An early debate in this research tradition was whether network organizations represented an organizational form intermediate between markets and hierarchies (Eccles, 1981; Thorelli, 1986; Williamson, 1991) or whether they represented an entirely new organizational form characterized by unique logics of exchange (Powell, 1990) similar to those described in research on embeddedness (see above). While the latter perspective seems to have prevailed, one can still ask a more fundamental question about whether the form really exists or is just a reification of organizational networks (cf., Podolny \& Page, 1998). Since organizations are already thought to be embedded in a network of economic and social relations, do we need to posit a new organizational form in order to theorize about, say, what industry conditions lead to more or stronger ties (e.g., should we expect more cooperative ties among, say, cultural industries)? It does not help that "network organization" can refer to a logic of governance (Jones et al., 1997), a collection 
of semi-autonomous firms (Miles \& Snow, 1986), or an organization with "new" features such as flat hierarchy, empowered workers, self-governing teams, heavy use of temporary structures (e.g., project teams, task forces), lateral communication, knowledge-based, etc. (van Alstyne, 1997; Birkinshaw \& Hagstrom, 2000; Hales, 2002). Adding to the linguistic chaos, some authors call these organizational forms "networks" and pronounce that, in the 21st century, firms must transform themselves from organizations into networks (Palmer \& Richards, 1999), confusing those who think of organizations as already consisting of networks. With all of this, it is perhaps no surprise that studies of network organizations have generated "diverse, varied, inconsistent, and contradictory" findings (Sydow \& Windeler, 1998). However, attempts to bring order to this area continue (Baker \& Faulkner, 2002).

\section{Board Interlocks}

Empirical research on board interlocks (ties among organizations through a member of one organization sitting on the board of another) has a long history in sociology and management (for an excellent review, see Mizruchi, 1996). Early board interlock work was dominated by resource dependence and class perspectives which saw interlocks as a means to (a) manage organizational dependencies (Pfeffer, 1972; Pfeffer \& Salancik, 1978) and (b) maintain power and control for social elites (Domhoff, 1967; Palmer, 1983; Pennings, 1980; Useem, 1979). While the primary objective in both research streams was identifying the causes of interlock ties (Pfeffer, 1972; Palmer, 1983; Zajac, 1998), some of this early research used interlocks to predict similarity in organizational behaviors (Mizruchi, 1989).

In recent years, the focus has shifted toward an informational perspective that sees interlocks as a means by which organizations reduce uncertainties and share information about acceptable and effective corporate practices. Scholars have used board interlocks to explain the diffusion of poison pills (Davis, 1991), corporate acquisition behavior (Haunschild, 1993), the adoption of organizational structures (Palmer, Jennings \& Zhou, 1993), CEO pay premiums (Geletkanycz, Boyd \& Finkelstein, 2001), joint venture formation (Gulati \& Westphal, 1999), and the use of imitation strategies in general (Westphal, Seidel \& Stewart, 2001). Several studies highlight the uncertainty reduction benefits of interlocks by arguing that they are more important in uncertain than certain environments (Carpenter \& Westphal, 2001; Geletkanycz \& Hambrick, 1997). One development in this literature, paralleling developments in the social capital literature, is that researchers are beginning to study the contingencies that determine when interlocks have the effects they do (Davis \& Greve, 1997; Gulati \& Westphal, 1999; Haunschild \& Beckman, 1998).

\section{Joint Ventures and Inter-firm Alliances}

Over the last twenty years, research on joint ventures and inter-firm alliances has proliferated (for a review, see Gulati, 1998). There appears to be a growing consensus that inter-organizational alliances and joint ventures have significant impacts on firm-level outcomes such as the performance of startups and new firms (Baum \& Calabrese, 2000; Stuart, 2000), firm valuations (Das, Sen \& Sengupta, 1998), organizational learning (Anand \& Khanna, 2000; Kale, Singh \& Perlmutter, 2000; Kraatz, 1998; Oliver, 2001), and innovation (Powell, Koput \& Smith-Doerr, 1996). 
Like the board interlock literature, and unlike many other areas of network investigation, the joint ventures/alliances literature has focused as much on the antecedents of networks as on their outcomes. A variety of approaches are used to explain why organizations form joint ventures and alliances and how they choose their partners. One view, echoing both transaction cost economics and the logic of resource dependency, is that alliances can be used to reduce a firm's exposure to uncertainty, risk, and opportunism (Gulati, 1995; Starkey, Barnatt \& Tempest, 2000). Another view, with links to institutional theory, is that alliances are made with larger, higher status firms in order to obtain access to resources and legitimacy (Stuart, 2000).

A third perspective focuses on what can be learned from alliance partners. According to the learning perspective, joint ventures and alliances provide access to information and knowledge resources that are difficult to obtain by other means and which improve firm performance and innovation (Ilinitch, D'Aveni \& Lewin, 1996; Kale et al., 2000; Kogut, 2000; Oliver, 2001; Powell et al., 1996; Rindfleisch \& Moorman, 2001; Rosenkopf \& Nerkar, 2001). These ideas are of course identical to the information side of the social capital literature, a point made explicitly by Burt (2003). While much of the work in this area focuses on dyadic relations, a more nuanced statement of the learning perspective argues that inter-firm network structures (not just dyadic relations between firms) affect learning and innovation (Kogut, 2000; Oliver, 2001; Powell et al., 1996). For example, Powell et al. (1996, p. 119) suggest that collaborations among biotechnology firms form inter-organizational learning cycles, as follows: Because information is dispersed among organizations and is the source of competitive advantage, in this industry, $R \& D$ collaborations provide firms with experience managing ties and access to more diverse sources of information which in turn increase firms' centrality and their subsequent ties.

\section{Knowledge Management}

The term "knowledge management" may soon disappear as practitioners rush to disassociate themselves from the relatively unsuccessful effort to use technological solutions to help organizations store, share and create new knowledge. The current mantra is that knowledge creation and utilization are fundamentally human and above all social processes (Brown \& Duguid, 2000; Davenport \& Prusak, 1998). One thread (which suffers from a lack of rigorous empirical research) is based on communities of practice (Brown \& Duguid, 1991; Lave \& Wenger, 1991; Orr, 1996; Tyre \& von Hippel, 1997; Wenger, 1998). The basic idea is that new practices and concepts emerge from the interaction of individuals engaged in a joint enterprise; the classic example is members of a functional department, such as claims processors in an insurance firm. The processes in community of practice theory resemble those of traditional social influence theory (Friedkin \& Johnsen, 1999), which emphasizes homogeneity of beliefs, practices, and attitudes as an outcome. They also overlap with and would strongly benefit from revisiting classic social psychology work (Homans, 1950; Newcomb, 1961) on the processes connecting agreement, similarity and interaction in groups, not to mention network diffusion research (Rice \& Aydin, 1991; Rogers, 1995).

Another thread is based on transactive memory (Hollingshead, 1998; Moreland, Argote \& Krishnan, 1996; Rulke \& Galaskiewicz, 2000; Wegner, 1987). Here the notion is that 
knowledge is distributed in different minds, and to make use of it effectively, individuals need to know who knows what (see social cognition section, below). In addition, Borgatti and Cross (2003) suggest that individuals need to have certain kinds of relationships (e.g., mutual accessibility, low partner-specific transaction costs) in order to utilize each others' knowledge. Transactive memory research contrasts with community of practice theory in its view of knowledge as remaining distributed even after being accessed, and in its lack of interest in how knowledge is generated in the first place.

\section{Social Cognition}

The term "social cognition" could easily include the transactional memory research reviewed above. However, in practice, it refers to the work of an entirely separate set of researchers who investigate the perception of networks. This area grows out of the informant accuracy research of the 1970s and 1980s (Bernard, Killworth, Kronenfeld \& Sailer, 1985), which was concerned with the methodological implications of respondents' inability to report their interactions accurately. Today, the interest is more theoretical and centered on the respondent's model of the entire network in which they are embedded, rather than their own ties. One stream of research takes as premise that cognition of the network determines interaction, and interaction in turn changes the network (Carley \& Krackhardt, 1996). A specific variant is concerned with the consequences of accurate perceptions of the network. For example, Krackhardt (1990) relates accurate perceptions to power, and, in a case study (Krackhardt, 1992), suggests that a union failed to succeed in unionizing a plant because it didn't understand the 'who respects whom' network among the employees (see also Baron \& Markman, 2003).

Another stream of research considers how actors develop the perceptions that they do. Within this stream, some approach this as modeling the level of actor accuracy. For example Casciaro (1998) found that an actor's personality, hierarchical position, and centrality in the network affected the accuracy of her perception of the network (see also Kenny, 1994). Another approach seeks to uncover patterns in perceptual errors. For example, several studies investigate tendencies for respondents to over-report ties to high status individuals (Brewer, 2000; Krebs \& Denton, 1997; Webster, 1995) and to see themselves as more central than others do (Johnson \& Orbach, 2002; Kumbasar, Romney \& Batchelder, 1994). The social cognition field clearly has much to offer the field of transactive memory, since groups can exploit the knowledge of their members only to the extent that their cognitive maps of 'who knows what' and 'who knows who knows what' are accurate.

\section{Group Processes}

A well-established area of research, with roots in classical social psychology (e.g., Allen, 1977; Homans, 1950; Newcomb, 1961), is concerned with how physical proximity, similarity of beliefs and attitudes, amount of interaction, and affective ties are interrelated. For example, in parallel streams of work, Friedkin and Johnsen $(1990,1999)$ and Carley (1991) have developed network models of how interacting individuals influence each other to produce homogeneity of beliefs. A nice review of the culture-cognition-networks intersection is provided by Kilduff and Corley (2000). For reviews of the effects of proximity on social 
interaction, see Kiesler and Cummings (2002), Oldham, Cummings and Zhou (1995), and Rice and Gattiker (2000).

A special case of the work on social proximity is homophily theory (see McPherson, Smith-Lovin \& Cook, 2001, for a review). Homophily refers to the tendency for people to interact more with their own kind-whether by preference or induced by opportunity constraints (McPherson \& Smith-Lovin, 1987) — as defined by such individual characteristics as race, gender, educational class, organizational unit, and so on. Recent organizational research on homophily has focused on its effects on group and individual performance outcomes (e.g., Ibarra, 1992; Krackhardt \& Stern, 1988; Reagans \& Zuckerman, 2001). On the positive side, interacting exclusively with similar others is thought to be efficient to the extent that similarity (a) facilitates transmission of tacit knowledge (Cross, Borgatti \& Parker, 2001, p. 229), (b) simplifies coordination (Ancona \& Caldwell, 1992; O'Reilly, Caldwell \& Barnett, 1989), and (c) avoids potential conflicts (Pelled, Eisenhardt \& Xin, 1999; Pfeffer, 1983). On the other hand, limiting communication among dissimilar others prevents a group from reaping the benefits of diversity and promotes us-vs.-them thinking (Krackhardt \& Stern, 1988). At the individual level, homophily is seen as a mechanism maintaining inequality of status for minorities within organizations. For example, echoing Brass (1985), Ibarra (1992) suggests that if men have more power in an organization, homophily implies that men's networks will contain more powerful people (i.e., other men) while women's networks will include less powerful people (i.e., women), limiting their social capital.

Other recent organizational network research on traditional social psychological topics includes work on conflict (Joshi, Labianca \& Caligiuri, 2002; Labianca, Brass \& Gray, 1998; Nelson, 1989), social referent choices (Shah, 1998), leadership (Pastor et al., 2002), and ethical behavior (Brass, Butterfield \& Skaggs, 1998; Nielsen, 2003). A renewed interest in the interaction between personality and network position is evident in Mehra et al. (2001), who suggest that high self-monitors are more likely to achieve positions of high centrality, and Burt, Janotta and Mahoney (1998), who relate personality to structural holes.

There is also a large body of continuing work on the evolution of group structure, ranging from empirical investigations of network change (Burkhardt \& Brass, 1990; Burt, 2000; Shah, 2000), to general mathematical models of change (Doreian \& Stokman, 1997; Snijders, 2001), to the fast-growing area of agent-based simulation studies (for a review, see Macy \& Willer, 2002). For example, Carley (1991) uses agent-based models to investigate group stability, while Zeggelink $(1994,1995)$ examines the growth of friendship networks, and Macy and Skvoretz (1998) simulate the development of trust networks.

\section{Dimensions of Network Research}

In this section, we examine the dimensions along which network studies vary, including direction of causality, level of analysis, explanatory mechanisms, and explanatory goals. The first two dimensions, while important, are more methodological than the last two, and we do not use them to actually classify work. Rather, they are included here in order to point out some peculiarities of network research, such as the relative dearth of work on network antecedents. The last two dimensions are more substantive, and we use them as the 
basis for a typology of network research (focusing on network consequences). 'Explanatory mechanisms' refers to how network ties are seen to function, whereas 'explanatory goals' refers to what exactly is being explained. The choice of dimensions is intuitive and reflects our belief that what is of essence in organizational research is explanation. It will be apparent that both dimensions map onto traditional debates within and outside of network research.

\section{Direction of Causality}

A fundamental dimension distinguishing among network studies is whether the studies are about the causes of network structures or the consequences. The bulk of network research has been concerned with the consequences of networks. One reason for this has to do with networks being a relatively young field whose first order of business was to achieve legitimacy. A rational strategy for gaining legitimacy is to show that network variables have consequences for important outcome variables that traditional fields already care about. Until networks had legitimacy, there was little point in trying to publish papers on how networks come to be or change over time.

Another reason for favoring consequences has been the structuralist heritage of the field. Since sociologists began to dominate network research in the 1970s, the proposition that an actor's position in a network has consequences for the actor has occupied a central place in network thinking. This is the structuralist paradigm championed by Blau (1977) and especially Mayhew (1980) and expressed in the network context by Wellman (1988). In general, networks are seen as defining the actor's environment or context for action and providing opportunities and constraints on behavior. Hence, studies that examine the consequences of networks are typically consistent with the structuralist agenda. In contrast, studies that examine the causes of network variables often clash with structuralism because they explain the network in terms of actor personalities and latent propensities (e.g., Mehra et al., 2001), which is anathema to the strong structuralist position (Mayhew, 1980).

To be fair, though, there is much more work on network antecedents than people give the field credit for, and the volume is increasing rapidly. The work is not very visible in part because there isn't a single area of research called 'network change.' Rather, work on change is embedded in the various substantive areas (e.g., Gulati \& Gargiulo, 1999; Madhavan, Koka \& Prescott, 1998; Shah, 2000). For example, the majority of recent work on inter-organizational networks is about explaining how and why organizations form ties and select partners (whether interlocking directorates or alliances or supply chains). Similarly, the large literature on the effects of proximity and homophily (McPherson et al., 2001) is about network causes, as is the growing area of agent-based models of networks (Macy \& Willer, 2002). In addition, almost all of the hundreds of articles on networks contributed by physicists in the last few years are focused on the evolution of networks (for a review, see Newman, 2002).

\section{Levels of Analysis}

Levels of analysis are so basic as to often escape notice. However, in the network case, there are some subtleties that make the dimension worth attending to. We start by observing that network data are fundamentally dyadic, meaning that we observe a value for each pair 
of nodes (e.g., whether actor A and actor B are friends or not; the number of e-mail messages exchanged by actor A and actor B), rather than for each node (e.g., age or gender of each actor). Hence, we can clearly formulate hypotheses at the dyadic level. Dyadic hypotheses essentially predict the ties of one social relation with the ties of another relation measured on the same actors. For example, Gulati and Gargiulo (1999, p. 1446) hypothesize that previous ties among two organizations increase the probability of an alliance between them in the future. But since the data can be aggregated to higher levels, hypotheses can be tested not only at the dyadic level but at the actor and whole network levels as well (not to mention mixed-level hypotheses, as when we use gender to explain who talks to whom).

In traditional research, we typically define levels of analysis in terms of the scope and complexity of the entities being studied (hence, organizations represent higher levels than persons), and this dimension tends to be an important distinction among studies and their authors (leading to frequent efforts to "bridge the micro-macro gap"). However, in network research, the situation is subtly and deceptively different, because the obvious levels of analysis (dyadic, actor and network) do not necessarily correspond in a simple way to the type of entities being studied. For example, suppose we examine how an actor's centrality in the communication network of an organization relates to her ability to innovate and solve problems (e.g., Perry-Smith \& Shalley, 2003). This is an actor-level analysis, one step up (i.e., more aggregate, fewer values) from the dyadic level. Now suppose we look at the communication networks of the top management team in 50 separate firms and correlate the density of each network with some aspect of firm performance (e.g., Athanassiou \& Nigh, 1999). This, as we would expect, is a network- or group-level analysis, a step up from the actor level. But now suppose we do a network analysis of alliances among biotech firms, hypothesizing that firms with more alliance partners will be more successful (e.g., Powell et al., 1996). Surprisingly, we are now back at the actor level of analysis, probably invoking the same arguments that were used for the first actor-level hypothesis. This is not unusual in network research, where micro and macro can be very similar theoretically and methodologically (see Katz \& Lazer, 2003, for a similar point of view). This does not mean that we expect every theory that applies to networks of persons to apply as well to networks of organizations, since the agents have different capabilities and the relations have different meanings. It is just that structural explanations are much more likely to scale than are individualist or essentialist explanations, a fundamental tenet of the physics literature on networks (Barabasi, 2002).

\section{Consequences of Networks}

We turn now to developing a typology of studies, limiting our attention to research on the consequences of networks, which make up the majority of the literature. This research can be fruitfully cross-classified according to two classic dimensions: explanatory goals and explanatory mechanisms. In the following pages, we explain each dimension, construct a 2-by-2 table, and then summarize by describing four canonical types of studies corresponding to the cells of the table. We begin with explanatory goals.

Explanatory goals: performance vs. homogeneity. Consider the difference between a social capital study such as Burt's (1992) attempt to explain promotion rates in terms of 
aspects of an actor's ego-network and a diffusion study such as Davis's (1991) study of the diffusion of corporate practices like poison pills through board interlocks. We point to two key differences. First, the perspective in the social capital study is more evaluative, concentrating on the benefits of social position. Indeed, the evaluative aspect is prominent in virtually all social capital studies, including those focusing on the so-called "dark side." In contrast, the diffusion study is more interested in the process by which practices, for good or ill, spread through a system.

Second, the social capital study emphasizes the possibilities for action that social ties provide the individual, whereas the diffusion study is implicitly about how the network changes the actor (in the sense of adopting a practice or developing an attitude). Like social attitude formation (Erickson, 1988) and social influence studies (Friedkin \& Johnsen, 1999), network diffusion studies are exemplars of a structuralist tradition that emphasizes constraints (DiMaggio \& Powell, 1983, p. 149), while the social capital literature concentrates on opportunities (Gargiulo \& Benassi, 2000). The actor in social capital work is generally a very active agent who exploits the network position she finds herself in (or creates for herself). While Burt (1992) stops short of saying so, many of his readers (e.g., Steier \& Greenwood, 2000) seem to add a rational actor assumption to social capital theory to the effect that actors deliberately choose their ties (i.e., manipulate the network structure) specifically in order to maximize gain. This instrumental, individual-oriented aspect of social capital work contrasts with the environmental determinism that is found in much diffusion (e.g., Valente, 1995) and social influence (Friedkin \& Johnsen, 1999) research.

In general, the difference between the social capital and diffusion studies mirrors the traditional difference between the fields of strategy and organization theory (particularly institutional theory), and the classical tension between agency and structure. More concretely, the distinction can also be framed in terms of the goals of the research. Social capital studies seek to explain variation in success (i.e., performance or reward) as a function of social ties, whereas diffusion and social influence studies seek to explain homogeneity in actor attitudes, beliefs and practices, also as a function of social ties. While variation and homogeneity are two sides of the same coin, the difference in perspective is telling.

Explanatory mechanisms: structuralist vs. connectionist. Another way in which network studies differ from each other is in how they treat ties and their functions. Consider individual-level social capital studies. There are two discernible streams of individual social capital research. One is represented by the work of Coleman (1990) and Burt (1992). In this perspective, the focus is on the structure or configuration of ties in the ego-network. It is a structural, topological approach that tends to neglect the content of the ties and focuses on the patterns of interconnection. In the other, connectionist, stream, represented by the work of Lin (2001) and others (e.g., Snijders, 1999), the focus is on the resources that flow through social ties. Ties are seen, often quite explicitly, as conduits through which information and aid flow (the "traffic" in Atkin's (1974) formulation). In this conception, an actor is successful because she can draw on the resources controlled by her alters, including information, money, power, and material aid. This perspective is also implicit in the social support literature (see Walker et al., 1994) and in most network research on entrepreneurs (e.g., Baron \& Markman, 2003; Shane \& Stuart, 2002). Burt (1992, p. 11) discusses the difference between these two streams in terms of the how (structuralist) and the who (con- 
nectionist). See Podolny (2001, p. 33) for a related, but incompatible, distinction between ties as pipes (over which resources flow) and ties as prisms (providing third parties with cues of node quality).

Although Burt (1992) places himself in the structuralist camp, his arguments for the information and control benefits of structural holes are drawn from both camps, and nicely illustrate the difference. The argument for information benefits states that an actor can maximize the amount of non-redundant information he receives through his contacts if the contacts are unconnected to each other. His reasoning is that if $\mathrm{A}$ and $\mathrm{B}$ are friends, then they will share information, and there is no reason for ego to have ties to both of themassuming the total number of ties an actor can have is limited, it is better to have a tie with just one of the pair and have the other tie go to someone unconnected to them. This is a connectionist argument. In contrast, the arguments for the control benefits of structural holes are structuralist and do not explicitly address flows. For example, one argument is divide-and-conquer: if your adversaries are connected, then they can coordinate against you, but if they are not, you can deal with them one by one. Another argument is the bidding war: if the adversaries both want the same thing and they are not connected to each other, they can be played off each other. These mechanisms have much in common with those found in the literature on experimental exchange networks (e.g., Cook \& Yamagishi, 1992; Lovaglia, Skvoretz, Markovsky \& Willer, 1995), in which topological explanations are used to the exclusion of flow arguments (see Walker, Thye, Simpson, Lovaglia, Willer \& Markovsky, 2000, for a current review).

The distinction that we refer to as structuralist vs. connectionist (or topology vs. flow or girders vs. pipes) is loosely related to Granovetter's (1992) distinction of structural vs. relational embeddedness and is the same distinction that occasioned much debate in the network diffusion literature under such labels as "equivalence vs. cohesion" and "positional vs. relational" (Burt, 1987). The connectionist (flows/pipes/cohesion/relational) perspective implies an interpersonal transmission process among those with pre-existing social ties using micro-mechanisms such as modeling (you use your PDA when I interact with you, so I begin to see myself with one) and congruence (I like you, and you like the Lady Huskies basketball team, so I like them too). The structuralist (topological/girders/equivalence/positional) view says that two nodes will have similar outcomes (e.g., adopt the same point of view) because they occupy structurally similar positions, even if there is no tie connecting them. For example, we might expect all people who are very central in advice networks to develop similarly jaundiced views of the constantly ringing telephone, even though the two people are not connected. Even if they were corrected, the mechanism yielding homogeneity is the common type of social environment, not a transmission from one to the other, as in the flow conception. Another mechanism of this type was proposed by Burt (1987), who argued that structurally equivalent actors recognize each other as comparable (even if they haven't met) and imitate aspects of each other. A similar idea surfaces in institutional theory under the label of mimetic isomorphism (DiMaggio \& Powell, 1983).

Typology of studies focusing on network consequences. Using the two dimensions of research on network consequences (explanatory goals and explanatory mechanisms), we can cross-classify network thinking into a 2-by-2 table, as shown in Table 1 . This gives us four canonical types of network studies, which for convenience we label "structural 
Table 1

Typology of research on consequences of network factors

\begin{tabular}{lll}
\hline & Social capital (performance variation) & Diffusion (social homogeneity) \\
\hline Structuralist (topology) & Structural capital & Environmental shaping \\
Connectionist (flows) & Social access to resources & Contagion \\
\hline
\end{tabular}

capital," "social access to resources," "environmental shaping," and "contagion." As a kind of summary of the discussion above, we describe each in turn.

Structural capital. These comprise the topological or structuralist variant of social capital studies. At the actor level, these studies focus on the benefits to actors of either occupying central positions in the network (e.g., Brass \& Burkhardt, 1993; Powell et al., 1996) or having an ego-network with a certain structure (e.g., Burt, 1992, 1997; Burt, Hogarth \& Michaud, 2000; Coleman, 1990). The actor is typically seen as a rational, active agent who exploits her position in the network in order to maximize gain. The actor's position in the network is described in terms of a desirable abstract pattern of ties, such as having a sparse ego-network or being located along the shortest path between otherwise unconnected actors. The benefits to the actor are principally a function of the topology of the local network, and ties are implicitly conceived of as forming a leverageable structure (Markovsky, Skvoretz, Willer, Lovaglia \& Erger, 1993). At the network level of analysis, structural capital studies seek to relate the network structure of a group to its performance (e.g., Athanassiou \& Nigh, 1999). This kind of study is one of the oldest in social network research, with dozens if not hundreds of exemplars, starting with the work of Bavelas (1950) at MIT, who investigated the relation between centralization and group performance (see the review by Shaw, 1971).

Resource access. These studies comprise the connectionist flavor of social capital studies. In these studies, an actor's success is a function of the quality and quantity of resources controlled by the actor's alters (e.g., Anand \& Khanna, 2000; Koka \& Prescott, 2000; Oliver, 2001; Stuart, 2000). Ego's ties with alters are conduits through which ego can access those resources. Different kinds of ties have different capacities for extracting resources (Borgatti \& Cross, 2003). As with structural capital studies, actors are typically seen implicitly as rational, active agents who instrumentally form and exploit ties to reach objectives. Most studies of this type are focused on the individual, and are often based on ego-network data alone. Research in the stakeholder and resource dependency traditions can fit here, particularly when the work portrays an actor as actively trying to co-opt those with whom it has dependencies.

Convergence. Studies of this type seek to explain common attitudes and practices in terms of similar network environments, usually conceptualized as centrality or structural equivalence (e.g., Galaskiewicz \& Burt, 1991). Actors are structurally equivalent to the extent they are connected to the same third parties, regardless of whether they are tied to each other (Lorrain \& White, 1971). A classic paper in this vein is Erickson's (1988) use of structural equivalence to explain common attitude formation. Similarly, DiMaggio and Powell (1983, p. 148) and DiMaggio (1986, p. 360) use measures of structural equivalence to model 
the notion of organizational isomorphism. The mechanisms generating similarity between two organizations have to do with sharing the same environments and/or recognition of each other as appropriate role models. In general, studies in the tradition of institutional theory fit here.

Contagion. Studies of this type seek to explain shared attitudes, culture, and practice through interaction (e.g., Davis, 1991; Geletkanycz \& Hambrick, 1997; Harrison \& Carroll, 2002; Haunschild, 1993; Krackhardt \& Kilduff, 2002; Molina, 1995; Sanders \& Hoekstra, 1998). The spread of an idea, practice, or material object is modeled as a function of interpersonal transmission along friendship or other durable channels. Ties are conceived of as conduits or roads along which information or influence flow. Seen from the point of view of the group as a whole, actors are mutually influencing and informing each other in a process that creates increasing homogeneity within structural subgroups. The ultimate distribution of ideas is a function of the structure of the underlying friendship network. Seen from the point of view of a single actor, her adoption of a practice is determined by the proportion of nodes surrounding her that have adopted, while the timing of adoption is a function of the lengths of paths connecting her to other adoptees. Work on communities of practice (e.g., Wenger, 1998) fits this category, although researchers in that field resist "reduction" to network terms and use terms like mutual engagement and interaction instead of network ties.

\section{Conclusion}

Salancik (1995, p. 348) argued that network research was not theoretical. If this was valid in 1995, it certainly is not today, as this review might indicate. The 1990s saw network theories emerge in virtually every traditional area of organizational scholarship, including leadership, power, turnover, job satisfaction, job performance, entrepreneurship, stakeholder relations, knowledge utilization, innovation, profit maximization, vertical integration, and so on. In this paper, we have reviewed a number of these areas, providing thumbnail sketches of the current thinking in each area.

In addition, we have proposed a typology of network research, which cross-classifies network studies according to the classic dimensions of explanatory mechanisms and explanatory goals or styles. The dimension of explanatory goals/styles distinguishes between an orientation toward modeling variation in performance and other value-laden outcomes, and an orientation toward modeling homogeneity in actor attributes, such as attitudes or practices. This dimension is related to the classic tension between agency and structure in organization studies. A big change in the 1990s was the growth of research in the former category, reflecting a strong shift toward agency in the traditional balance between agency and structure in network research. It could also be seen, by some network-theoretic purists, as a co-opting of network notions by a more conventional individualist perspective. The dimension of explanatory mechanisms distinguishes between structuralist and connectionist types of explanations (which we trace to underlying conceptions of ties as functioning as girders vs. pipes), and maps onto a traditional debate in network diffusion research between cohesive/relational and structural equivalence sources of adoption. What is new here is that 
this seemingly arcane distinction may be traceable to different underlying conceptions of how ties work (girders vs. flows), and applies to all kinds of network research, including distinguishing between the two major variants of social capital theory.

\section{Acknowledgments}

We thank Jean Bartunek, Dan Brass, Kathleen Carley, Tiziana Casciaro, Ron Dufresne, Fabio Fonti, David Krackhardt, Joe LaBianca, Marta Geletkanycz, Ron Rice, and Peter Rivard for critical comments, as well as Arar Han for her research assistance.

\section{References}

Achrol, R. S. 1997. Changes in the theory of inter-organizational relations: Toward a network paradigm. Journal of the Academy of Marketing Science, 25(1): 56-71.

Adler, P. S., \& Kwon, S. W. 2002. Social capital: Prospects for a new concept. Academy of Management Review, 27(1): 17-40.

Allen, T. 1977. Managing the flow of technology. Cambridge, MA: MIT Press.

van Alstyne, M. 1997. The state of network organization: A survey in three frameworks. Journal of Organizational Computing and Electronic Commerce, 7(2/3): 83-151.

Anand, B. N., \& Khanna, T. 2000. Do firms learn to create value? The case of alliances. Strategic Management Journal, 21: 295-315.

Ancona, D. G., \& Caldwell, D. F. 1992. Bridging the boundary: External activity and performance in organizational teams. Administrative Science Quarterly, 37: 634-665.

Athanassiou, N., \& Nigh, D. 1999. The impact of U.S. company internationalization on top management team advice networks: A tacit knowledge perspective. Strategic Management Journal, 20(1): 83-92.

Atkin, R. H. 1974. Mathematical structures in human affairs. London: Heineman Educational.

Baker, W. E., Faulkner, R. R., \& Fisher, G. A. 1998. Hazards of the market: The continuity and dissolution of inter-organizational market relations. American Sociological Review, 63: 147-177.

Baker, W. E., \& Faulkner, R. F. 2002. Interorganizational networks. In J. A. C. Baum (Ed.), The Blackwell companion to organizations. Oxford: Blackwell Publishers Ltd.

Baldwin, T. T., Bedell, M. D., \& Johnson, J. L. 1997. The social fabric of a team-based M.B.A. program: Network effects on student satisfaction and performance. 40(6): 1369-1397.

Barabasi, A. L. 2002. Linked: The new science of networks. New York: Perseus Publishing.

Baron, R. A., \& Markman, G. D. 2003. Beyond social capital: The role of entrepreneurs' social competence in their financial success. Journal of Business Venturing, 18(1): 41-60.

Barthes, R. 1977. Image-music-text. London: Fontana.

Baum, J. A. C., \& Calabrese, T. 2000. Don't go it alone: Alliance network composition and startups' performance in Canadian biotechnology. Strategic Management Journal, 21(3): 267-294.

Bavelas, A. 1950. Communication in task-oriented groups. Journal of the Acoustical Society of America, 22: 271-282.

Bernard, H. R., Killworth, P. D., Kronenfeld, D., \& Sailer, L. 1985. On the validity of retrospective data: The problem of informant accuracy. Annual Review of Anthropology, 13: 495-517.

Birkinshaw, J., \& Hagstrom, P. (Eds.). 2000. The flexible firm: Capability management in network organizations. Oxford University Press on Demand.

Blau, P. 1977. Inequality and heterogeneity. New York: Free Press.

Blumberg, B. F. 2001. Cooperation contracts between embedded firms. Organization Studies, 22(5): 825-852.

Borgatti, S. P., \& Cross, R. 2003. A relational view of information seeking and learning in social networks. Management Science, 49(4): 432-445. 
Boxman, E. A. W., De Graaf, P. M., \& Flap, H. D. 1991. The impact of social and human capital on the income attainment of Dutch managers. Social Networks, 13: 51-73.

Bradach, J. L., \& Eccles, R. G. 1989. Price authority and trust: From ideal types to plural forms. American Review of Sociology, 15: 97-118.

Brass, D., Butterfield, K., \& Skaggs, B. 1998. Relationships and unethical behavior: A social network perspective. Academy of Management Review, 23: 14-31.

Brass, D. J. 1984. Being in the right place: A structural analysis of individual influence in an organization. Administrative Science Quarterly, 29: 518-539.

Brass, D. J. 1985. Men's and women's networks: A study of interaction patterns and influence in an organization. Academy of Management Journal, 28: 327-343.

Brass, D. J., \& Burkhardt, M. E. 1993. Potential power and power use: An investigation of structure and behavior. Academy of Management Journal, 36: 440-470.

Brass, D. J., \& Krackhardt, D. 1999. The social capital of 21 st century leaders. In J. G. Hunt \& R. L. Phillips (Eds.), Out-of-the-box leadership: 179-194. Stamford, CT: JAI Press.

Brewer, D. D. 2000. Biases in perceiving one's own social position and social ties as evolved psychological mechanisms. Paper presented at the Proceedings of the Presentation on Social Theory and Networks on Ethnography, Cologne.

Brown, J. S., \& Duguid, P. 1991. Organizational learning and communities-of-practice: Toward a unified view of working, learning, and innovation. Organization Science, 2(1): 40-57.

Brown, J. S., \& Duguid, P. 2000. The social life of information. Cambridge: Harvard Business School Press.

Burkhardt, M. E., \& Brass, D. J. 1990. Changing patterns or patterns of change: The effect of a change in technology on social network structure and power. Administrative Science Quarterly, 35: 104-127.

Burt, R. 1992. Structural holes: The social structure of competition. Cambridge: Harvard University Press.

Burt, R. 2001. Structural holes versus network closure as social capital. In N. Lin, K. S. Cook, \& R. S. Burt (Eds.), Social capital: Theory and research: 31-56. New York: Aldine de Gruyter.

Burt, R. S. 1987. Social contagion and innovation: Cohesion versus structural equivalence. American Journal of Sociology, 92(6): 1287-1335.

Burt, R. S. 1997. The contingent value of social capital. Administrative Science Quarterly, 42: 339-365.

Burt, R. S. 1998. The gender of social capital. Rationality and Society, 10(1): 5-46.

Burt, R. S. 2000. Decay functions. Social Networks, 22(1): 1-28.

Burt, R. S. 2003. The social origin of good ideas. Unpublished manuscript. Available at http://gsbwww.uchicago.edu/fac/ronald.burt/research/.

Burt, R. S., Hogarth, R. M., \& Michaud, C. 2000. The social capital of French and American managers. Organization Science, 11(2): 123-147.

Burt, R. S., Janotta, J., \& Mahoney, J. 1998. Personality correlates of structural holes. Social Networks, 20(1): 63-87.

Carley, K. 1991. A theory of group stability. American Sociological Review, 56(3): 331-354.

Carley, K. M., \& Krackhardt, D. 1996. Cognitive inconsistencies and non-symmetric friendship. Social Networks, 18(1): 1-27.

Carpenter, M. A., \& Westphal, J. D. 2001. The strategic context of external network ties: Examining the impact of director appointments on board involvement in strategic decision making. Academy of Management Journal, 44(4): 639-660.

Casciaro, T. 1998. Seeing things clearly: Social structure, personality, and accuracy in social network perception. Social Networks, 20(4): 331-351.

Coleman, J. 1990. Foundations of social theory. Cambridge, MA: Belknap Press.

Cook, K. S., \& Yamagishi, T. 1992. Power in exchange networks: A power-dependence formulation. Social Networks, 14(3/4): 245-265.

Cross, R., Borgatti, S. P., \& Parker, A. 2001. Beyond answers: Dimensions of the advice network. Social Networks, 23(3): 215-235.

Dacin, T. M., Ventresca, M. J., \& Beal, B. D. 1999. The embeddedness of organizations: Dialogue and directions. Journal of Management, 25(3): 317-356.

Das, S., Sen, P. K., \& Sengupta, S. 1998. Impact of strategic alliances on firm valuation. Academy of Management Journal, 41(1): 27-41.

Davenport, T. H., \& Prusak, L. 1998. Working knowledge. Cambridge: HBS Press. 
Davis, G. F. 1991. Agents without principles? The spread of the poison pill through the inter-corporate network. Administrative Science Quarterly, 36: 583-613.

Davis, G. F., \& Greve, H. R. 1997. Corporate elite networks and governance changes in the 1980s. American Journal of Sociology, 103(1): 1-37.

DiMaggio, P. 1986. Structural analysis of organizational fields: A blockmodel approach. Research in Organizational Behavior, 8: 335-370.

DiMaggio, P., \& Louch, H. 1998. Socially embedded consumer transactions: For what kinds of purchases do people most often use networks? American Sociological Review, 63: 619-637.

DiMaggio, P., \& Powell, W. 1983. The iron cage revisited: Institutional isomorphism and collective rationality in organizational fields. American Sociological Review, 48: 147-160.

Domhoff, G. W. 1967. Who rules America? Englewood Cliffs, NJ: Prentice-Hall.

Doreian, P., \& Stokman, F. 1997. The dynamics and evolution of social networks. In: P. Doreian \& F. Stokman (Eds.), Evolution of Social Networks: 1-17. Amsterdam: G \& B Pubs.

Eccles, R. G. 1981. The quasifirm in the construction industry. Journal of Economic Behavior and Organization, 2: 335-357.

Erickson, B. 1988. The relational basis of attitudes. In B. Wellman \& S. Berkowitz (Eds.), Social structures: A network approach: 99-121. NY: Cambridge University Press.

Fernandez, R. M., Castilla, E. J., \& Moore, P. 2000. Social capital at work: Networks and employment at a phone center. American Journal of Sociology, 105(5): 1288-1356.

Friedkin, N. E., \& Johnsen, E. C. 1990. Social influence and opinions. Journal of Mathematical Sociology, 15: 193-205.

Friedkin, N. E., \& Johnsen, E. C. 1999. Social influence networks and opinion change. Advances in Group Processes, 16: 1-29.

Galaskiewicz, J., \& Burt, R. S. 1991. Interorganization contagion in corporate philanthropy. Administrative Science Quarterly, 36(1): 88-105.

Gargiulo, M., \& Benassi, M. 1999. The dark side of social capital. In S. Gabbay \& R. Leenders (Eds.), Social capital and liability: 298-322. Norwell, MA: Kluwer.

Gargiulo, M., \& Benassi, M. 2000. Trapped in your own net? Network cohesion, structural holes, and the adaptations of social capital. Organization Science, 11(2): 183-196.

Geletkanycz, M. A., Boyd, B. K., \& Finkelstein, S. 2001. The strategic value of CEO external directorate networks: Implications for CEO compensation. Strategic Management Journal, 22(9): 889-898.

Geletkanycz, M. A., \& Hambrick, D. C. 1997. The external ties of top executives: Implications for strategic choice and performance. Administrative Science Quarterly, 42(4): 654-681.

Granovetter, M. 1985. Economic action and social structure: The problem of embeddedness. American Journal of Sociology, 91(3): 481-510.

Granovetter, M. 1992. Problems of explanation in economic sociology. In N. Nohria \& R. G. Eccles (Eds.), Networks and organization: Structure, form and action: 25-56. Boston: HBS Press.

Granovetter, M. S. 1973. The strength of weak ties. American Journal of Sociology, 6: 1360-1380.

Gulati, R. 1995. Does familiarity breed trust? The implications of repeated ties for contractual choice in alliances. Academy of Management Journal, 38(1): 85-112.

Gulati, R. 1998. Alliances and networks. Strategic Management Journal, 19(4): 293-317.

Gulati, R., \& Gargiulo, M. 1999. Where do interorganizational networks come from? American Journal of Sociology, 104(5): 1439-1493.

Gulati, R., \& Westphal, J. D. 1999. Cooperative or controlling? The effects of CEO-board relations and the content of interlocks on the formation of joint ventures. Administrative Science Quarterly, 44(3): 473-506.

Hales, C. 2002. 'Bureaucracy-lite' and continuities in managerial work. British Journal of Management, 13(1): 51-66.

Hansen, M. T. 1999. The search-transfer problem: The role of weak ties in sharing knowledge across organization subunits. Administrative Science Quarterly, 44(1): 82-111.

Harrison, R. J., \& Carroll, G. R. 2002. The dynamics of cultural influence networks. Computational and Mathematical Organization Theory, 8(1): 5-30.

Haunschild, P. R. 1993. Interorganizational imitation: The impact of interlocks on corporate acquisition activity. Administrative Science Quarterly, 38(4): 564-592. 
Haunschild, P. R., \& Beckman, C. M. 1998. When do interlocks matter?: Alternate sources of information and interlock influence. Administrative Science Quarterly, 43(4): 815-844.

Hollingshead, A. B. 1998. Communication, learning, and retrieval in transactive memory systems. Journal of Experimental Social Psychology, 34(5): 423-442.

Homans, G. 1950. The human group. NY: Harcourt, Brace and World.

Ibarra, H. 1992. Homophily and differential returns: Sex differences in network structure and access in an advertising firm. Administrative Science Quarterly, 37: 422-447.

Ilinitch, A. Y., D’Aveni, R. A., \& Lewin, A. Y. 1996. New organizational forms and strategies for managing in hypercompetitive environments. Organization Science, 7(3): 211-221.

Ingram, P., \& Roberts, P. W. 2000. Friendships among competitors in the Sydney hotel industry. American Journal of Sociology, 106(2): 387-423.

James, E. H. 2000. Race-related differences in promotions and support: Underlying effects of human and social capital. Organization Science, 11(5): 493-508.

Jarillo, J. C. 1988. On strategic networks. Strategic Management Journal, 9(1): 31-39.

Johnson, J. C., \& Orbach, M. K. 2002. Perceiving the political landscape: Ego biases in cognitive political networks. Social Networks, 24: 291-310.

Jones, C., Hesterly, W. S., \& Borgatti, S. P. 1997. A general theory of network governance: Exchange conditions and social mechanisms. Academy of Management Journal, 22(4): 911-945.

Joshi, A., Labianca, G., \& Caligiuri, P. M. 2002. Getting along long distance: Understanding conflict in a multinational team through network analysis. Journal of World Business, 37(4): 277-284.

Kale, P., Singh, H., \& Perlmutter, H. 2000. Learning and protection of proprietary assets in strategic alliances: Building relational capital. Strategic Management Journal, 21: 217-237.

Katz, N., \& Lazer, D. 2003. Building effective intra-organizational networks: The role of teams. Unpublished manuscript. Available at http://www.ksg.harvard.edu/teamwork/.

Kenny, D. A. 1994. Interpersonal perception: A social relations analysis. New York: Guilford.

Kiesler, S., \& Cummings, J. N. 2002. What do we know about proximity and distance in work groups? A legacy of research, distributed work. Cambridge, MA: MIT Press.

Kilduff, M., \& Corley, K. G. 2000. Organizational culture from a network perspective. In N. Ashkanasy, C. Wilderom, \& M. Peterson (Eds.), Handbook of organizational culture \& climate: 211-221. Thousand Oaks, CA: Sage.

Kilduff, M., \& Krackhardt, D. 1994. Bringing the individual back in: A structural analysis of the internal market for reputation in organizations. Academy of Management Journal, 37(1): 87-108.

Kogut, B. 2000. The network as knowledge: Generative rules and the emergence of structure. Strategic Management Journal, 21(3): 405-425.

Koka, B. R., \& Prescott, J. E. 2000. Strategic alliances as social capital: A multidimensional view. Strategic Management Journal, 23: 795-816.

Kraatz, M. S. 1998. Learning by association? Interorganizational networks and adaptation to environmental change. Academy of Management Journal, 41(6): 621-643.

Krackhardt, D. 1990. Assessing the political landscape: Structure, cognition, and power in organizations. Administrative Science Quarterly, 35: 342-369.

Krackhardt, D. 1992. The strength of strong ties: The importance of philos in organizations. In N. Nohria \& R. G. Eccles (Eds.), Networks and organizations: Structure, form and action: 216-239. Cambridge, MA: Harvard Business School Press.

Krackhardt, D., \& Kilduff, M. 2002. Structure, culture and Simmelian ties in entrepreneurial firms. Social Networks, 24(3): 279-290.

Krackhardt, D., \& Porter, L. W. 1985. When friends leave: A structural analysis of the relationship between turnover and stayer's attitudes. Administrative Science Quarterly, 30: 242-261.

Krackhardt, D., \& Porter, L. W. 1986. The snowball effect: Turnover embedded in communication networks. Applied Psychology, 71: 50-55.

Krackhardt, D., \& Stern, R. N. 1988. Informal networks and organizational crises-An experimental simulation. Social Psychology Quarterly, 51(2): 123-140.

Krebs, D. L., \& Denton, K. 1997. Social illusions and self-deception: The evolution of biases in person perception. In J. A. Simpson \& D. T. Kenrick (Eds.), Evolutionary social psychology: 21-47. Hillsdale, N.J.: Erlbaum. 
Kristeva, J. 1980. Desire in language: A semiotic approach to literature and art. New York: Columbia University Press

Kumbasar, E., Romney, K. A., \& Batchelder, W. H. 1994. Systematic biases in social perception. American Journal of Sociology, 100: 477-505.

Labianca, G., Brass, D. J., \& Gray, B. 1998. Social networks and perceptions of intergroup conflict: The role of negative relationships and third parties. Academy of Management Journal, 41: 55-67.

Lave, J., \& Wenger, E. 1991. Situated learning: Legitimate peripheral participation. Cambridge, UK: Cambridge University Press.

Lin, N. 1982. Social resources and instrumental action. In P. Marsden \& N. Lin (Eds.), Social structure and network analysis: 131-145. Beverly Hills, CA: Sage.

Lin, N. 1988. Social resources and social mobility: A structural theory of status attainment. In R. Breiger (Ed.), Social mobility and social structure. Cambridge: Cambridge University Press.

Lin, N. 2001. Social capital: A theory of social structure and action. Cambridge: Cambridge University Press.

Lorrain, F., \& White, H. C. 1971. The structural equivalence of individuals in social networks. Journal of Mathematical Sociology, 1: 49-80.

Lovaglia, M. J., Skvoretz, J., Markovsky, B., \& Willer, D. 1995. Assessing fundamental power differences in exchange networks: Iterative GPI. Current Research in Social Psychology, 1(2): 8-15.

Macy, M., \& Skvoretz, J. 1998. The evolution of trust and cooperation between strangers: A computational model. American Sociological Review, 63: 638-660.

Macy, M. W., \& Willer, R. 2002. From factors to actors: Computational sociology and agent-based modeling. Annual Review of Sociology, 28: 143-166.

Madhavan, R., Koka, B. R., \& Prescott, J. E. 1998. Networks in transition: How industry events (re)shape interfirm relationships. Strategic Management Journal, 19(5): 439-459.

Markovsky, B., Skvoretz, J., Willer, D., Lovaglia, M. J., \& Erger, J. 1993. The seeds of weak power: Extending network exchange theory. American Sociological Review, 58: 197-209.

Mayhew, B. 1980. Structuralism versus individualism. Part 1: Shadowboxing in the dark. Social Forces, 80: 335-365.

McGuire, G. M. 2000. Gender, race, ethnicity, and networks: The factors affecting the status of employees' network members. Work Occupation, 27(4): 500-523.

McPherson, J. M., \& Smith-Lovin, L. 1987. Homophily in voluntary organizations. American Sociological Review, 52: 370-379.

McPherson, J. M., Smith-Lovin, L., \& Cook, J. M. 2001. Birds of a feather: Homophily in social networks. Annual Review of Sociology, 27: 415-444.

Mehra, A., Kilduff, M., \& Brass, D. J. 2001. The social networks of high and low self-monitors: Implications for workplace performance. Administrative Science Quarterly, 46: 121-146.

Miles, R. E., \& Snow, C. C. 1986. Network organisations, new concepts for new forms. California Management Review, 28: 62-73.

Miles, R. E., \& Snow, C. C. 1992. Causes of failure in network organizations. California Management Review, 34: 52-72.

Mizruchi, M. S. 1989. Similarity of political behavior among large American corporations. American Journal of Sociology, 95(2): 401-424.

Mizruchi, M. S. 1996. What do interlocks do? An analysis, critique, and assessment of research on interlocking directorates. Annual Review of Sociology, 22: 271-298.

Molina, J. L. 1995. Analysis of networks and organizational culture: A methodological proposal. Revista Espanola de Investigaciones Sociologicas, 71-72: 249-263.

Montgomery, J. D. 1998. Toward a role-theoretic conception of embeddedness. American Journal of Sociology, 104(1): 92-125.

Moreland, R. L., Argote, L., \& Krishnan, R. 1996. Socially shared cognition at work: Transactive memory and group performance. In J. L. Nye \& A. M. Brower (Eds.), What's social about social cognition? Research on socially shared cognition in small groups: $57-84$. Thousand Oaks, CA: Sage.

Nelson, R. E. 1989. The strength of strong ties, social networks, and intergroup conflict in organizations. Academy of Management Journal, 32: 377-401.

Newcomb, T. 1961. The acquaintance process. New York: Holt, Rinehardt \& Winston.

Newman, M. E. J. 2002. The structure and function of networks. Computer Physics Communications, 147: 40-45. 
Nielsen, R. P. 2003. Corruption networks and implications for ethical corruption reform. Journal of Business Ethics, 42(2): 125-149.

Oldham, G. R., Cummings, A., \& Zhou, J. 1995. The spatial configuration of organizations: A review of the literature and some new research directions. Research in Personnel and Human Resource Management, 13: $1-37$.

Oliver, A. L. 2001. Strategic alliances and the learning life-cycle of biotechnology firms. Organization Studies, 22(3): 467-489.

O'Reilly, C. A., Caldwell, D. F., \& Barnett, W. P. 1989. Work group demography, social integration, and turnover. Administrative Science Quarterly, 34: 21-37.

Orr, J. 1996. Talking about machines: An ethnography of a modern job. Ithaca, New York: Cornell University Press.

Palmer, D. 1983. Broken ties: Interlocking directorates and intercorporate contagion. Administrative Science Quarterly, 28: 40-55.

Palmer, D. A., Jennings, P. D., \& Zhou, X. 1993. Late adoption of the multidivisional form by large U.S. corporations: Institutional, political, and economic accounts. Administrative Science Quarterly, 38(1): 100 131.

Palmer, J., \& Richards, I. 1999. Get knitted: Network behaviour in the new economy. The Journal of Knowledge Management, 3(3): 191-202.

Pastor, J.-C., Meindl, J. R., \& Mayo, M. C. 2002. A network effects model of charisma attributions. Academy of Management Journal, 45(2): 410-420.

Pelled, L. H., Eisenhardt, K. M., \& Xin, K. R. 1999. Exploring the black box: An analysis of work group diversity, conflict, and performance. Administrative Science Quarterly, 44: 1-28.

Pennings, J. M. 1980. Interlocking directorates. NY: Jossey-Bass.

Perry-Smith, J. E., \& Shalley, C. E. 2003. The social side of creativity: A static and dynamic social network perspective. Academy of Management Review, 28(1): 89-107.

Pfeffer, J. 1972. Size and composition of corporate boards of directors: The organization and its environment. Administrative Science Quarterly, 17: 218-228.

Pfeffer, J. 1983. Organizational demography. In L. L. Cummings \& B. M. Staw (Eds.), Research in organizational behavior: Vol. 5, 299-357. Greenwich, CT: JAI Press.

Pfeffer, J., \& Salancik, G. R. 1978. The external control of organizations: A resource dependence perspective. New York: Harper \& Row.

Podolny, J. M. 2001. Networks as the pipes and prisms of the market. American Journal of Sociology, 107(1): 33-60.

Podolny, J. M., \& Baron, J. N. 1997. Resources and relationships: Social networks and mobility in the workplace. American Sociological Review, 62: 673-693.

Podolny, J. M., \& Page, K. L. 1998. Network forms of organization. Annual Review of Sociology, 24: 57-76.

Portes, A. 1998. Social capital: Its origins and applications in modern sociology. Annual Review of Sociology, 24: $1-24$.

Portes, A., \& Landolt, P. 1996. The downside of social capital. The American Prospectives, 94: 18-21.

Portes, A., \& Sensenbrenner, J. 1993. Embeddedness and immigration-Notes on the social determinants of economic action. American Journal of Sociology, 98(6): 1320-1350.

Powell, W. W. 1990. Neither market nor hierarchy: Network forms of organization. Research on Organizational Behavior, 12: 295-336.

Powell, W. W., Koput, K. W., \& Smith-Doerr, L. 1996. Interorganizational collaboration and the locus of innovation: Networks of learning in biotechnology. Administrative Science Quarterly, 41(1): 116-145.

Putnam, R. D. 2000. Bowling alone: The collapse and revival of American community. New York: Simon \& Schuster.

Reagans, R., \& Zuckerman, E. W. 2001. Networks, diversity, and productivity: The social capital of corporate R\&D teams. Organization Science, 12(4): 502-517.

Renzulli, L. A., Aldrich, H., \& Moody, J. 2000. Family matters: Gender, networks, and entrepreneurial outcomes. Social Forces, 79(2): 523-546.

Rice, R. E., \& Aydin, C. 1991. Attitudes toward new organizational technology: Network proximity as a mechanism for social information processing. Administrative Science Quarterly, 36: 219-244. 
Rice, R. E., \& Gattiker, U. 2000. New media and organizational structuring. In F. Jablin \& L. Putnam (Eds.), New handbook of organizational communication: 544-581. Newbury Park, CA: Sage.

Rindfleisch, A., \& Moorman, C. 2001. The acquisition and utilization of information in new product alliances: A strength-of-ties perspective. Journal of Marketing, 65: 1-18.

Rogers, E. M. 1995. Diffusion of innovations (4th ed.). New York: The Free Press.

Rosenkopf, L., \& Nerkar, A. 2001. Beyond local search: Boundary-spanning, exploration, and impact in the optical disc industry. Strategic Management Journal, 22(4): 287.

Rulke, D. L., \& Galaskiewicz, J. 2000. Distribution of knowledge, group network structure, and group performance. Management Science, 46(5): 612-626.

Salancik, G. R. 1995. Wanted: A good network theory of organization. Administrative Science Quarterly, 40: 345-349.

Sanders, K., \& Hoekstra, S. K. 1998. Informal networks and absenteeism within an organization. Computational and Mathematical Organization Theory, 4(2): 149-163.

Seibert, S. E., Kraimer, M. L., \& Liden, R. C. 2001. A social capital theory of career success. Academy of Management Journal, 44(2): 219-247.

Seidel, M. L., Polzer, J. T., \& Stewart, K. J. 2000. Friends in high places: The effects of social networks on discrimination in salary negotiations. Administrative Science Quarterly, 45: 1-24.

Shah, P. P. 1998. Who are employees' social referents? Using a social network perspective to determine referent others. Academy of Management Journal, 41(3): 249-268.

Shah, P. P. 2000. Network destruction: The structural implications of downsizing. Academy of Management Journal, 43(1): 101-112.

Shane, S., \& Stuart, T. 2002. Organizational endowments and the performance of university start-ups. 48(1): $154-170$.

Shaw, M. E. 1971. Group dynamics: The psychology of small group behavior. NY: McGraw-Hill.

Snijders, T. A. B. 1999. Prologue to the measurement of social capital. The Tocqueville Review, 10(1): $27-44$.

Snijders, T. A. B. 2001. The statistical evaluation of social network dynamics. In M. E. Sobel \& M. P. Becker (Eds.), Sociological methodology-2001: 361-395. Boston and London: Basil Blackwell.

Snow, C. C., Miles, R. E., \& Coleman, H. J. 1992. Managing 21st century organizations. Organizational Dynamics, 20(3): 5-20.

Sparrowe, R. T., \& Liden, R. C. 1997. Process and structure in leader-member exchange. Academy of Management Review, 22: 522-552.

Sparrowe, R. T., Liden, R. C., Wayne, S. J., \& Kraimer, M. L. 2001. Social networks and the performance of individuals and groups. Academy of Management Journal, 44(2): 316-325.

Starkey, K., Barnatt, C., \& Tempest, S. 2000. Beyond networks and hierarchies: Latent organizations in the U.K. television industry. Organization Science, 11(3): 299-305.

Steier, L., \& Greenwood, R. 2000. Entrepreneurship and the evolution of angel financial networks. Organization Studies, 21(1): 163-192.

Stuart, T. E. 2000. Interorganizational alliances and the performance of firms: A study of growth and innovation. Strategic Management Journal, 21(8): 791-811.

Sydow, J., \& Windeler, A. 1998. Organizing and evaluating interfirm networks: A structurationist perspective on network processes. Organization Science, 9(3): 265-284.

Thorelli, H. B. 1986. Networks: Between markets and hierarchies. Strategic Management Journal, 7: 37-51.

Tsai, W. 2001. Knowledge transfer in intraorganizational networks: Effects of network position and absorptive capacity on business unit innovation and performance. Academy of Management Journal, 44(5): 996-1004.

Tyre, M. J., \& von Hippel, E. 1997. The situated nature of adaptive learning in organizations. Organization Science, 8(1): 71-84.

Useem, M. 1979. The social organization of the American business elite and participation of corporation directors in the governance of American institutions. American Sociological Review, 44(4): 553-572.

Uzzi, B. 1996. The sources and consequences of embeddedness for the economic performance of organizations: The network effect. American Sociological Review, 61: 674-698.

Uzzi, B. 1997. Social structure and competition in inter-firm networks: The paradox of embeddedness. Administrative Science Quarterly, 42: 35-67.

Uzzi, B. 1999. Embeddedness in the making of financial capital: How social relations and networks benefit firms seeking financing. American Sociological Review, 64: 481-505. 
Uzzi, B., \& Gillespie, J. J. 2002. Knowledge spillover in corporate financing networks: Embeddedness and the firms debt performance. Strategic Management Journal, 23: 595-618.

Valente, T. W. 1995. Network models of the diffusion of innovation. New York: Hampton Press.

Volker, B., \& Flap, H. 2001. Weak ties as a liability: The case of East Germany. Rationality and Society, 13(4): 397-428.

Walker, H. A., Thye, S. R., Simpson, B., Lovaglia, M. J., Willer, D., \& Markovsky, B. 2000. Network exchange theory: Recent developments and new directions. Social Psychology Quarterly, 63(4): 324-337.

Walker, J., Wasserman, S., \& Wellman, B. 1994. Statistical models for social support networks. In S. Wasserman \& J. Galaskiewicz (Eds.), Advances in social network analysis: 53-78. Thousand Oaks, CA: Sage.

Webster, C. M. 1995. Detecting context-based constraints in social perception. Journal of Quantitative Anthropology, 5: 285-303.

Wegner, D. M. 1987. Transactive memory: A contemporary analysis of the group mind. In B. Mullen \& G. R. Goethals (Eds.), Theories of group behavior: 185-208. New York: Springer.

Wellman, B. 1988. Structural analysis: From method and metaphor to theory and substance. In B. Wellman \& S. D. Berkowitz (Eds.), Social structures: A network approach: 19-61. New York: Cambridge University Press.

Wenger, E. 1998. Communities of practice: Learning, meaning, and identity. New York: Cambridge University Press.

Westphal, J. D., Seidel, M. D. L., \& Stewart, K. J. 2001. Second-order imitation: Uncovering latent effects of board network ties. Administrative Science Quarterly, 46(4): 717-747.

Williamson, O. E. 1975. Markets and hierarchies: Analysis and antitrust implications. New York: The Free Press.

Williamson, O. E. 1991. Comparative economic organization: The analysis of discrete structural alternatives. Administrative Science Quarterly, 36: 269-296.

Zajac, E. J. 1998. Interlocking directorates as an interorganizational strategy: A test of critical assumptions. Academy of Management Journal, 31(2): 428-438.

Zeggelink, E. P. H. 1994. Dynamics of structure: An individual oriented approach. Social Networks, 16: $295-333$.

Zeggelink, E. P. H. 1995. Evolving friendship networks: An individual-oriented approach implementing similarity. Social Networks, 17: 83-110.

Zukin, S., \& DiMaggio, P. 1990. Structures of capital: The social organization of the economy. Cambridge, MA: JAI Press.

Stephen P. Borgatti is an Associate Professor of Organization Studies at Boston College. He received his Ph.D. in Mathematical Social Science from the University of California, Irvine. His research interests include social networks, shared cognition, and computational models.

Pacey C. Foster is currently a doctoral candidate in Organization Studies at Boston College. His doctoral research, supported by a Program on Negotiation Graduate Research Fellowship, explores the impact of social networks on negotiations in cultural industries. His other research interests include the development of action learning theories that facilitate positive individual, group, and organizational change. 